\title{
Naujų panaudoto branduolinio kuro saugojimo konteinerių naujojoje Ignalinos AE saugykloje šiluminis ivvertinimas
}

\author{
Vytautas Šimonis, \\ Artūras Šmaižys, \\ Povilas Poškas \\ Branduolinès inžinerijos \\ problemu laboratorija, \\ Lietuvos energetikos institutas, \\ Breslaujos g. 3, LT-44403 Kaunas \\ El.paštas: simonis@mail.lei.lt
}

Pateiktas naujojoje Ignalinos AE panaudoto branduolinio kuro tarpinio saugojimo saugykloje numatomų naudoti saugojimo konteinerių CONSTOR RBMK-1500/M2 šiluminis įvertinimas. Skaitinis modeliavimas atliktas naudojant JAV sukurtą programų paketą (kodą) ALGOR pavieniame konteineryje ir konteineryje, esančiame saugykloje, su ką tik pakrautu panaudotu branduoliniu kuru, prieš tai laikytu vandens baseinuose 7(5) metus, ir po 50 metų saugojimo saugykloje. Konservatyviai prièmus ribinius žiedinio krepšio su kuro pluoštais efektinius laidumus, sutampančius su krepšio iš aliuminio lydinio laidumu (pirmasis atvejis) arba su vidinio krepšio ịkrovos efektiniu laidumu (antrasis atvejis), nustatytas temperatūrų pasiskirstymas ir ribinès konteinerių temperatūros.

Skaičiavimai parodè, kad pavienio konteinerio su ką tik pakrautu panaudotu branduoliniu kuru, prieš tai laikytu baseinuose 7(5) metus, maksimalios įkrovos (ŠIEL’ų paviršiaus) ir konteinerio išorinio šoninio paviršiaus temperatūros pirmuoju atveju siekia 238 ir $56^{\circ} \mathrm{C}$, o antruoju atveju -302 ir $58^{\circ} \mathrm{C}$. Konteinerio, esančio saugykloje, atitinkamos temperatūros pirmuoju atveju siekia 257 ir $87^{\circ} \mathrm{C}$, o antruoju atveju -318 ir $90^{\circ} \mathrm{C}$. Po 50 metų saugojimo saugykloje konteinerių su panaudotu branduoliniu kuru maksimalios įkrovos temperatūros sumažèja $120-140^{\circ}$, o šoninio paviršiaus - apie $30^{\circ}$. Tikrasis žiedinio krepšio efektinis laidumas yra tarp pirmojo ir antrojo atvejų laidumų, todèl po 7(5) metų kuro laikymo baseinuose maksimalios ŠIEL’ų paviršiaus temperatūros bus ne didesnès už maksimalią leistiną $300^{\circ} \mathrm{C}$ temperatūrą, o pavienio konteinerio išorinio paviršiaus temperatūros - už transportuojamiems konteineriams leistiną $85^{\circ} \mathrm{C}$ temperatūrą.

Raktažodžiai: RBMK-1500 panaudotas branduolinis kuras, konteineris, saugykla, šilumą išskiriantis elementas, temperatūra, liekamasis šilumos srautas

\section{IVADAS}

Ignalinos atominëje elektrinëje panaudoto branduolinio kuro tarpiniam saugojimui pasirinktas vadinamasis „sauso“ saugojimo būdas. Šiuo atveju panaudotas kuras po tam tikro privalomo laikymo vandens baseinuose (ne trumpiau kaip 5 metai) yra sudedamas ị GNS (Vokietija) gamybos metalinius CASTOR ${ }^{\circledR}$ RBMK-1500 arba gelžbetoninius CONSTOR $^{\circ}$ RBMK-1500 konteinerius ir atviroje arba dengtoje aikštelèje (saugykloje) gali būti laikomas dar apie 50 metų. Šiuo metu prie IAE įrengtoje ir kelis kartus modifikuotoje tarpineje panaudoto branduolinio kuro saugykloje yra saugoma 120 CASTOR ir CONSTOR tipo konteineriu, kuriuose patalpinta per 6000 PBK rinklių. Saugykla jau yra užpildyta.
Visiškai uždarius atominę elektrinę, susidarys dar iki 18000 PBK rinklių, kurias reikia atitinkamai patalpinti ị konteinerius ir saugoti. Šiuo metu baigiama statyti nauja tarpinè panaudoto RBMK branduolinio kuro rinklių iš 1-ojo ir 2-ojo Ignalinos AE energetinių blokų saugykla, kurioje numatoma patalpinti iki 200 naujos konstrukcijos daug talpesnių GNS gamybos CONSTOR ${ }^{\circledR}$ RBMK-1500/M2 tipo konteineriu su visu likusiu PBK.

Šiluminiu požiūriu pagrindiniu parametru, lemiančiu pasirinktų konteinerių panaudojimą, yra maksimali leistina ŠIEL’ų paviršiaus temperatūra saugojimo metu ir konteinerių išorinio paviršiaus leistina temperatūra jų transportavimo metu. Projektuojančių organizacijų yra nustatyta, kad RBMK1500 reaktorių panaudoto branduolinio kuro, laikyto vandens 
baseinuose ne trumpiau kaip 5 metus, maksimalios ŠIEL’ų paviršiaus temperatūros turi būti ne didesnès nei $300{ }^{\circ} \mathrm{C}$ [1], nors kiti šaltiniai panašiam kurui nurodo ir aukštesnes leistinas temperatūras $-350{ }^{\circ} \mathrm{C}$ [2] ir net iki $380{ }^{\circ} \mathrm{C}$ [3]. Konteinerių išorinio paviršiaus leistina temperatūra transportavimo metu pagal TATENA reikalavimus [4] turi būti ne didesnè nei $85^{\circ} \mathrm{C}$.

Konteinerių šiluminị režimą sąlygoja patalpinto $\mathrm{PBK}$ liekamasis šilumos išsiskyrimas ir, aišku, konteinerio konstrukcija bei saugojimo sąlygos. Ignalinos AE buvo naudojamas įvairaus įsodrinimo - nuo $2 \mathrm{iki} 2,8 \%$ su erbio sugèrikliu ir be jo - branduolinis kuras. LEI mokslininkų skaičiavimai [5] parodè, kad labiausiai šilumos išsiskyrimas keičiasi pirmuosius 7 metus, kol kuras laikomas vandens baseinuose (1 pav.), vèliau tas kitimas stabilizuojasi ir monotoniškai mažèja per visą saugojimo laikotarpi. 1 pav. parodytas minimalaus (2\%) ir maksimalaus (2,8 \% su erbio sugèrikliu) ìsodrinimo vienos PBK rinklès liekamojo šilumos išsiskyrimo kitimas per 50 metų. IAE naudoto kitokio įsodrinimo branduolinio kuro liekamasis šilumos išsiskyrimas patenka tarp šių ribinių kreivių.

Norint saugoti panaudotą branduolinị kurą tokị ilgą laikotarpi, reikia gerai suprasti įvairius procesus, vykstančius pačiame konteineryje ir jam sąveikaujant su aplinka, bei užtikrinti daugeli reikalavimų tiek kuro pluoštams, tiek konteineriui, tiek saugyklai, kurioje konteineriai laikomi. Ankstesniuose darbuose $[6,7]$ buvo pateikti CASTOR ${ }^{\circledR}$ RBMK-1500 ir CONSTOR $^{\circledast}$ RBMK-1500 konteinerių šiluminio modeliavimo naudojant skaičiavimo kodą ALGOR (JAV) rezultatai. Nustatyta, kad šiluminiu požiūriu šie konteineriai visiškai tinka panaudoto branduolinio kuro, laikyto vandens baseinuose ne trumpiau kaip 5 metus, ilgalaikiam saugojimui. Metodiškai

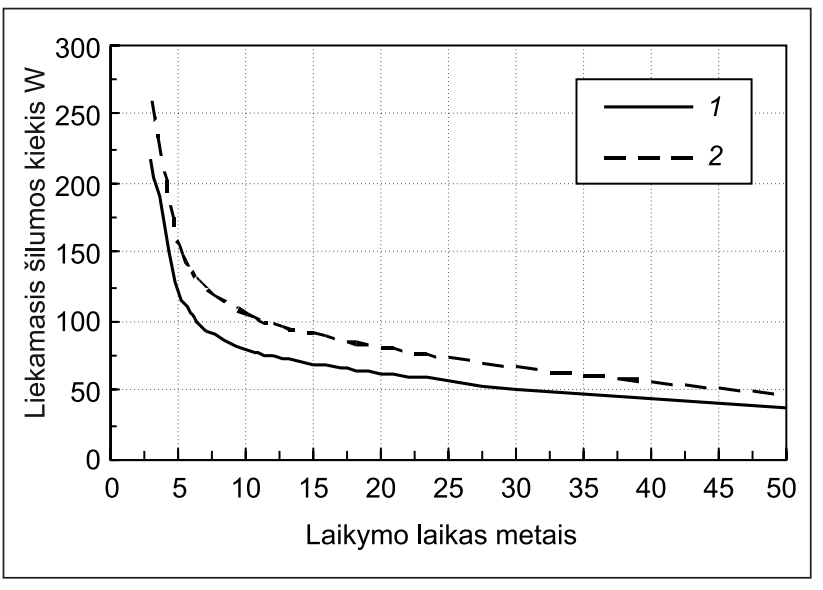

1 pav. Liekamojo šilumos išsiskyrimo priklausomumas nuo PBK rinklès laikymo, esant $2 \%$ (1) ir 2,8 \% su erbio sugèrikliu (2) kuro isodrinimui [5]

panašūs tyrimai buvo atlikti [8] darbe taikant skaičiavimo kodą FLUENT (JAV) konteinerių su panaudotu branduoliniu kuru iš suslègto vandens reaktorių (PWR) analizei.

Šiame darbe pateikiamas naujo tipo gelžbetoninių konteinerių CONSTOR ${ }^{\oplus}$ RBMK-1500/M2 panaudotam branduoliniam kurui saugoti naujojoje Ignalinos AE panaudoto branduolinio kuro tarpinio saugojimo saugykloje šiluminis ivertinimas normaliomis eksploatavimo sąlygomis.

\section{METODINIAI KLAUSIMAI}

Gelžbetoninio konteinerio CONSTOR ${ }^{\circledR}$ RBMK-1500/M2 (2 pav.) korpuso šoną sudaro du skirtingų gabaritų plieniniai cilindrai: vidinis $(1 a)$ ir išorinis $(1 b)$, kurių sienelès storis yra
2 pav. Principinès naujo tipo konteinerio (a) ir žiedinio krepšio $(b, c)$ schemos: 1a, $1 b$ - korpuso vidinis ir išorinis cilindrai; $1 c$ - korpuso užpildas; $1 d, 1 e$ - korpuso dugno plokštès; $1 f$ - žiedas; 2 - vidinis krepšys; 3 - žiedinis krepšys; 4 - dangtis; $5 a, 5 b$ - sandarinimo plokštes; 6 - apsauginè plokšté; 7 - apsauginis gaubtas

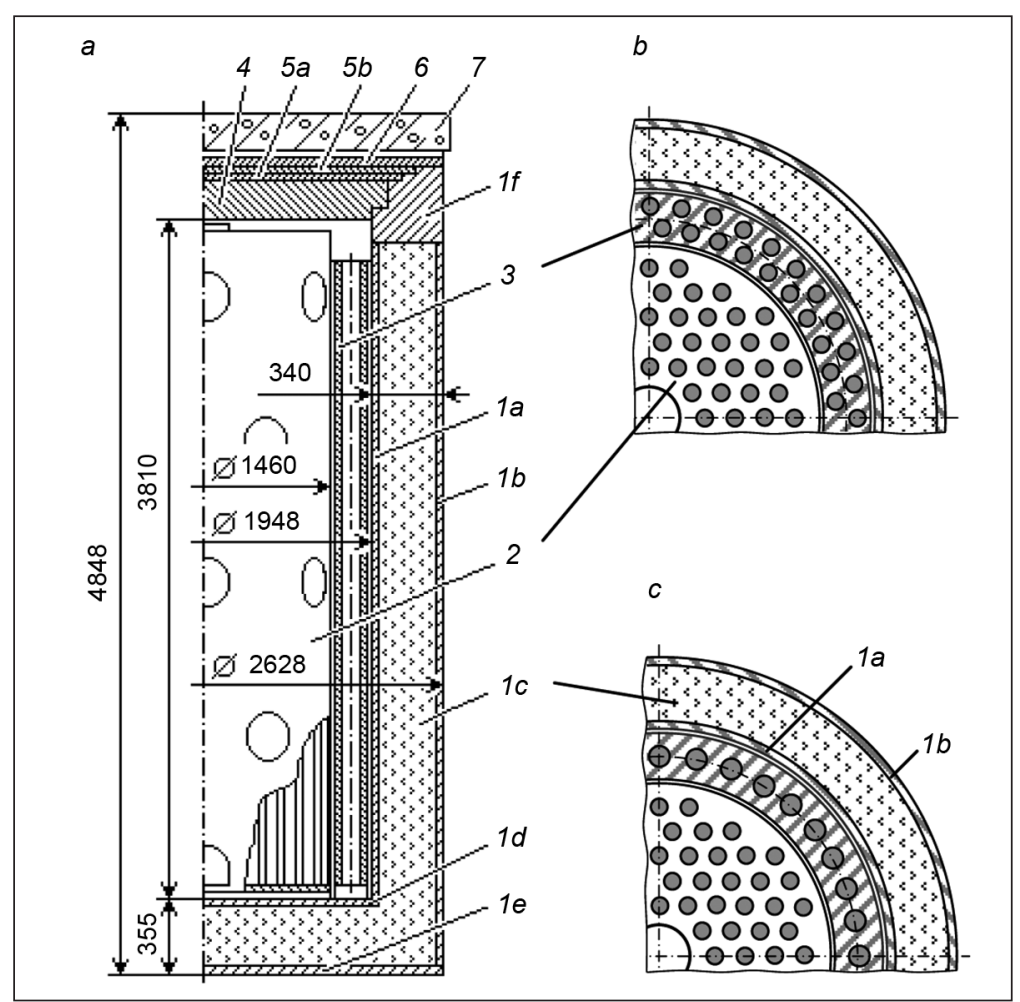




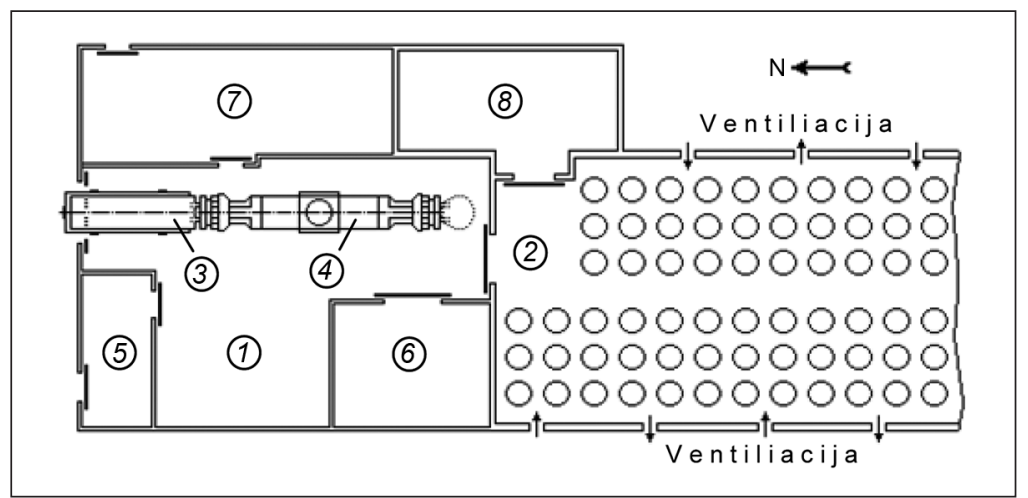

3 pav. Principine saugyklos schema: 1 - konteinerių prièmimo salè, 2 - konteinerių saugojimo salè, 3 - atvežtas konteineris, 4 - verstuvas (tuščiam konteineriui), 5 - iškonservavimo patalpa, 6 - konteinerių paruošimo patalpa, 7- aptarnavimo patalpos, 8 - „karštoji kamera“

0,04 m. Tarpcilindrinè erdvė yra užpildyta ekranuojančia medžiaga - sunkiuoju betonu CONSTORIT’u (1c). Analogiškai sudarytas korpuso dugnas - erdvė tarp dviejų plokščių $1 d$ ir 1e užpildoma sunkiuoju betonu. Bendras konteinerio sienos storis yra $0,34 \mathrm{~m}$. Konteinerio viršų formuoja masyvus metalinis žiedas $1 f$, kuris privirintas prie cilindrų galų. Žiede tvirtinami metalinis konteinerio dangtis 4, dvi metalinès sandarinimo plokštès $5 a$ ir $5 b$ ir metalinè apsauginè plokštė 6. Stacionariai laikomą konteinerị saugykloje iš viršaus gaubia gelžbetoninis apsauginis gaubtas 7 .

I konteinerio vidų talpinami du krepšiai su PBK: vidinis 32M tipo krepšys 2, naudotas ir ankstesniuose konteineriuose, ir papildomas, tik šiame konteineryje naudojamas, žiedinis krepšys 3 (2 pav.).Vidinis krepšys - tai specialus nerūdijančio plieno cilindrinis krepšys su dugnu ir 102 vamzdžiais, $\underset{1}{\mathrm{k} u-}$ riuos dedami 102 panaudoto branduolinio kuro pluoštai (t. y. 51 pusiau perpjauta PBK rinklè). Žiedinis krepšys - tai specialaus aliuminio lydinio karkasas, atsižvelgus ị konfigūraciją su 80 arba 40 kiaurymių (2 pav., $b, c$ ), ị kurias dedami PBK pluoštai arba nerūdijančio plieno penalai su pažeistais kuro pluoštais ar kuro liekanomis. Taigi maksimaliai ị toki konteineri galima pakrauti $102+80=182$ PBK pluoštus (ankstesniuose konteineriuose buvo kraunama tik po $102 \mathrm{PBK}$ pluoštus). Konteinerio gabaritai yra: skersmuo - $\varnothing 2,63 \mathrm{~m}$, aukštis - 4,85 m, pakrauto konteinerio masè - apie $116 \mathrm{t}$.

Visos konteinerio pakrovimo operacijos atliekamos vandenyje. Pakrovus abu krepšius, konteineris sandariai uždaromas dangčiu ir, išsiurbus vandeni, išdžiovinus bei vakuumavus, užpildomas heliu. Po to konteineris uždengiamas apsaugine plokšte ir išvežamas ị saugyklą. Čia konteineris galutinai paruošiamas saugojimui (užvirinamos sandarinimo plokštès), konteineris uždengiamas gelžbetoniniu apsauginiu gaubtu ir pastatomas saugyklos saugojimo salèje.

Principine baigiamos statyti naujos IAE PBK saugyklos schema parodyta 3 pav. Tai karkasinis dengtas statinys su sienomis, stogu ir labai tvirtu pagrindu. Iš esmès saugyklą sudaro dvi salès: konteinerių prièmimo salè 1 ir 200 konteinerių saugojimo salè 2. Siekiant palaikyti reikiamą šiluminị režimą, saugojimo salè yra natūraliai ventiliuojama. Saugykloje taip pat numatyta vadinamoji „karštoji kamera“ 8 , kurioje saugojimo laikotarpiu, reikalui esant, PBK bus perkraunamas ị kitą konteinerį.
Konteinerių šiluminei analizei, kaip ir ankstesniuose darbuose [6,7], buvo panaudotas JAV sukurtas programų paketas (kodas) ALGOR [9]. Tai pakankamai universali programa, leidžianti atlikti dvimatị ir trimatị šiluminị modeliavimą. Šiame darbe nagrinejjamas stacionarus dvimatis simetrinis konteinerio modelis cilindrinèse $r-z$ koordinatèse (4 pav.). Skaičiavimo modelyje visi konteinerio elementai modeliuojami atskiromis zonomis. Pagal aukštị VK (krepšys be dugno su PBK pluoštais) modeliuojamas trimis homogeninemis zonomis: 1 - pagrindinè aktyvioji, šilumą išskirianti ịkrovos zona 1 bei 2, 3 - apatine (2) ir viršutine (3) neaktyvios įkrovos zonos, kurias sudaro kuro rinklių galai.

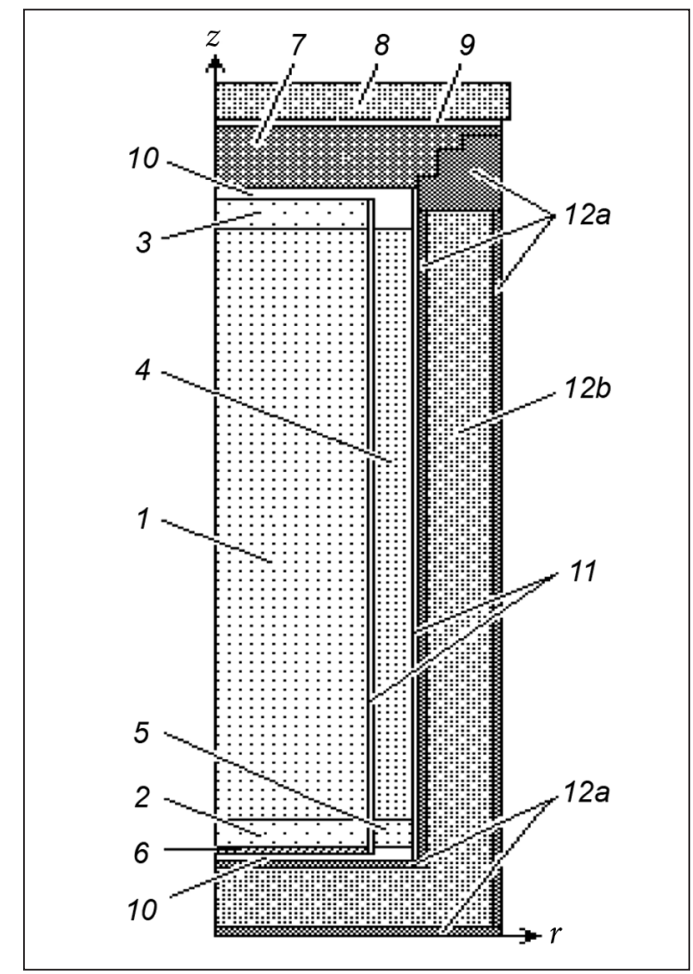

4 pav. Konteinerio šiluminio modeliavimo konceptualus modelis: 1 - VK aktyvioji įkrovos zona; 2, 3-VK apatinè ir viršutine neaktyvios jkrovos zonos; 4 - ŽK aktyvioji j̨krovos zona; 5 - ŽK apatinè neaktyvi jkrovos zona; 6 - krepšio dugnas; 7 - dangčių sistema; 8 - apsauginis gaubtas; 9 - oro plyšys; 10 - horizontalūs helio plyšiai; 11 - vertikalūs helio plyšiai; $12 a$ - metalinès korpuso dalys; $12 b$ - korpuso užpildas 
Krepšio dugnas yra apie $0,05 \mathrm{~m}$ storio ir sudaro atskirą zoną 6. ŽK su PBK pluoštais modeliuojamas dviem homogeninèmis zonomis: 1 - pagrindinè aktyvioji, šilumą išskirianti ikrovos zona 4 ir 2 - apatinè neaktyvi ikrovos zona 5 su kuro rinklių galais.

Konteinerio korpuso metalinès dalys modeliuojamos viena zona $12 a$, o sunkiojo betono užpildas - kita zona $12 b$. Konteinerio dangtis, sandarinimo ir apsauginè plokštės modeliuojami viena zona 7 , o gelžbetoninis apsauginis gaubtas - kita zona 8 . Horizontalūs helio plyšiai 10 , vertikalūs helio plyšiai 11 ir oro plyšys 9 taip pat modeliuojami atskiromis homogeninemis zonomis.

Faktiškai per vidinio ir žiedinio krepšiu i ikrovas bei helio plyšius šiluma perduodama laidumu, spinduliavimu bei konvekcija. Per konteinerio korpusą - tik laidumu, o nuo konteinerio paviršiaus - spinduliavimu bei natūraliaja konvekcija. Modeliuojant šilumos perdavimas per ikrovas buvo vertinamas, panaudojant efektinius kiekvienos ikrovos homogeninès zonos šilumos laidumo koeficientus, o per kitas zonas - panaudojant realius atitinkamų zonų šilumos laidumo koeficientus. Vidinio krepšio ịkrovos efektiniai laidumo koeficientai yra nustatyti branduolinių reaktorių projektavimo organizacijose modelinių eksperimentų metu. Tačiau žiedinio krepšio ịkrovos efektiniai laidumo koeficientai nèra žinomi, todèl skaičiuojant konservatyviai buvo analizuoti du ribiniai žiedinio krepšio efektinio laidumo atvejai: 1 - laidumas - kaip krepšio karkaso medžiagos, t. y. aliuminio lydinio; 2 - laidumas - kaip vidinio krepšio įkrovos efektinis laidumas. Tikrasis žiedinio krepšio ikkrovos efektinis laidumas turètų būti tarp šių dviejų ribinių atvejų.

Šilumos perdavimas per helio plyšius buvo vertinamas tik laidumu. Tačiau, siekiant įvertinti šilumos perdavimą ir kitais būdais, vertikalių helio plyšių šilumos laidumo koeficientai, remiantis [10] darbo rekomendacijomis, buvo padvigubinti.

Šilumos kiekis perduodamas natūraliaja konvekcija nuo konteinerio vertikalaus šoninio ir apsauginio gaubto horizontalaus viršutinio paviršiaus (konteinerio dugnas priimtas adiabatiniu) nustatomas iš lygties:

$$
q_{\text {konv }}=\alpha_{\text {konv }}\left(T_{\text {kont }}-T_{a}\right) \text {. }
$$

Šilumos atidavimo koeficientas dèl natūraliosios konvekcijos nuo vertikalaus šoninio konteinerio paviršiaus randamas iš kriterinès lygties [11]:

$$
\mathrm{Nu}=0,13 \mathrm{Ra}^{1 / 3}, \text { kai } \operatorname{Ra}>4 \cdot 10^{10}, \operatorname{Pr}>0,5
$$

Lemiantysis geometrinis dydis panašumo kriterijuose $\mathrm{Nu}$ ir Ra yra konteinerio aukštis.

Šilumos atidavimo koeficientas dèl natūraliosios konvekcijos nuo konteinerio apsauginio gaubto horizontalaus viršutinio paviršiaus randamas iš kriterinès lygties [11]:

$$
\mathrm{Nu}=0,15 \mathrm{Ra}^{1 / 3}, \text { kai Ra }>8 \cdot 10^{6}, \operatorname{Pr}>0,5 .
$$

Lemiantysis geometrinis dydis šiuo atveju yra pusẻ konteinerio spindulio. Taip nustatyti šilumos atidavimo koeficientai patikslinti iteraciniais skaičiavimais pagal realias paviršių temperatūras.

Šilumos kiekis, perduodamas spinduliavimu nuo konteinerio paviršiaus aplinkai, nustatomas iš lygties

$$
q_{\text {rad }}=\sigma \varepsilon\left(T^{4}{ }_{\text {kont }}-T^{4}\right) ;
$$

čia $\sigma=5,67 \cdot 10^{-8} \mathrm{~W} /\left(\mathrm{m}^{2} \cdot \mathrm{K}^{4}\right)$ - spinduliavimo konstanta; $\varepsilon$ - specialiai padengto konteinerio paviršiaus juodumo laipsnis $\varepsilon=0,93$.

Saulès spinduliavimo įtakos konteineriams naujojoje saugykloje vertinti nereikia, nes konteineriai saugomi uždaroje saugykloje ir tiesioginès Saulès ịtakos šiuo atveju nepatiria.

Skaičiuojant priimama: vidinio ir žiedinio krepšių ikrovų liekamieji šilumos išsiskyrimai, visų konteinerị sudarančių medžiagų šilumos laidumo (arba efektinio laidumo) koeficientai pagal konteinerio spindulị ir aukštị dèl temperatūros, aplinkos temperatūra, šilumos atidavimo nuo konteinerio paviršių natūraliąja konvekcija koeficientai bei konteinerio išorinio spinduliavimo paviršiaus juodumo laipsnis.

Skaičiavimo kode ALGOR visų konteinerio elementų fizikinès savybès ir ribinès sąlygos nurodomos specialiose elektroninèse lentelèse. Toliau, baigtinių elementų metodu sprendžiant diferencialines šilumos laidumo lygtis, atlikus skaičiavimus gaunami temperatūrų bei šilumos srautų pasiskirstymai konteinerio įkrovose ir korpuse.

Yra numatytos įvairios PBK patalpinimo konteinerio vidiniame ir išoriniame krepšiuose schemos. Tačiau realiai $\mathfrak{i}$ vidinị krepši bus dedamas tik $2 \%$ įsodrinimo PBK, kurio yra daugiausia [12] ir kuris šiuo metu vandens baseinuose laikomas 7-10 metų ir ilgiau. I žiedinị krepšį bus talpinamas likęs ivvairių ísodrinimų (tarp jų ir maksimalaus - 2,8 \%) kuras, baseinuose laikomas trumpiau. Todèl skaičiavimai atlikti realiai situacijai, t. y. vidiniame krepšyje yra $2 \%$ ịsodrinimo PBK, prieš tai vandens baseinuose laikytas 7 metus, o žiediniame krepšyje yra maksimalaus $-2,8 \%$ ịsodrinimo $\mathrm{PBK}$, prieš tai vandens baseinuose laikytas 5 metus (toliau sąlyginai žymima 7(5)).

\section{SKAIČIAVIMO REZULTATAI}

Skaičiavimai atlikti panaudotu branduoliniu kuru maksimaliai pakrautų pavienio konteinerio ir konteinerio, esančio saugykloje tarp kitų konteinerių, sąlygomis, konservatyviai prièmus du ribinius žiedinio krepšio ịkrovos efektinių laidumų atvejus: 1 - laidumas - kaip krepšio karkaso medžiagos - aliuminio lydinio (t. y. maksimalus galimas laidumas); 2 - laidumas - kaip vidinio krepšio ikkrovos efektinis laidumas (t. y. minimalus laidumas).

Kaip minèta, $\mathfrak{i}$ ką tik pakrauto konteinerio vidinị krepši dedamas ne trumpiau kaip 7 metus, o ị žiedini krepši - 
ne trumpiau kaip 5 metus vandens baseinuose laikytas panaudotas branduolinis kuras. Tokių 102 kuro pluoštų, patalpintų vidiniame krepšyje, liekamasis šilumos išsiskyrimas $-Q_{v}=4,77 \mathrm{~kW}$, o 80 kuro pluoštų, patalpintų žiediniame krepšyje $-Q_{\check{z}}=6,21 \mathrm{~kW}$ ir suminis liekamasis šilumos išsiskyrimas $-Q=10,98 \mathrm{~kW}$. Aplinkos temperatūra pavienio konteinerio atveju priimta $t_{a}=30{ }^{\circ} \mathrm{C}$, kuri atitinka vidutinę daugiametę karščiausio metų laiko temperatūrą Ignalinos regione. Aplinkos temperatūra konteinerio, esančio saugykloje, atveju priimta $t_{a}=35^{\circ} \mathrm{C}$, kuri yra $5^{\circ}$ didesnè dèl gretimų konteinerių įtakos.

5 pav. parodytas skaičiavimais gautas temperatūrų pasiskirstymas pavieniame ką tik pakrautame konteineryje pirmuoju (a) ir antruoju (b) ribiniais atvejais. Kaip matyti, maksimali temperatūra yra vidinio krepšio įkrovos centre ir siekia $238{ }^{\circ} \mathrm{C}$ pirmuoju atveju (a) ir $302{ }^{\circ} \mathrm{C}$ antruoju atveju (b). Laikoma, kad ši temperatūra atitinka centrinio įkrovos pluošto ŠIEL'ų paviršiaus temperatūras. Tolstant nuo centro tiek ašine, tiek radialine kryptimis temperatūros mažèja, tik radialine kryptimi temperatūros gradientai yra didesni. Žiedinio krepšio zonoje maksimalios temperatūros $107^{\circ} \mathrm{C}(a)$ ir $207^{\circ} \mathrm{C}(b)$ yra monotoniškai mažèjančios. Be to, konteinerių apsauginio gaubto maksimalios temperatūros $\left(\sim 32{ }^{\circ} \mathrm{C}\right)$ yra ženkliai mažesnès už konteinerių dugno maksimalias temperatūras $\left(\sim 69^{\circ} \mathrm{C}\right)$. Taip yra todèl, kad modeliuojant dugne buvo priimtos adiabatinès sąlygos, nors realiai tarp konteinerio dugno ir betoninio pagrindo bus apie $2 \mathrm{~cm}$ oro tarpas, ir dèl natūralios konvekcijos dugno temperatūros bus mažesnès.

5 pav. taip pat matyti, kad antruoju atveju maksimali vidinio krepšio ikkrovos temperatūra yra apie $60^{\circ}$ didesnè negu pirmuoju atveju ir siekia maksimalią leistiną $-300{ }^{\circ} \mathrm{C}$. Konteinerių šoninio paviršiaus maksimalios temperatūros $\left(56-58^{\circ} \mathrm{C}\right)$ yra mažesnès už maksimalią leistiną $\left(85^{\circ} \mathrm{C}\right)$ temperatūrą, nustatytą pagal konteinerių transportavimo reikalavimus.

Izotermų pasiskirstymas konteineryje, esančiame saugykloje, rodo, kad visos temperatūros gautos didesnès negu pavieniame konteineryje (6 pav.). Ikrovos maksimalios temperatūros padideja iki $20^{\circ}$, šoninio paviršiaus ir dugno - apie $30^{\circ}$, o apsauginio gaubto - apie $7^{\circ}$. Taip maksimali ikrovos temperatūra siekia $257^{\circ} \mathrm{C}$ pirmuoju atveju (a) ir $318^{\circ} \mathrm{C}$ antruoju atveju $(b)$. Žiedinio krepšio zonoje maksimalios temperatūros yra $136{ }^{\circ} \mathrm{C}(a)$ ir $227^{\circ} \mathrm{C}(b)$. Šoninio paviršiaus temperatūros siekia $90^{\circ} \mathrm{C}$, dugno $-99^{\circ} \mathrm{C}$ ir apsauginio gaubto $-39^{\circ} \mathrm{C}$.

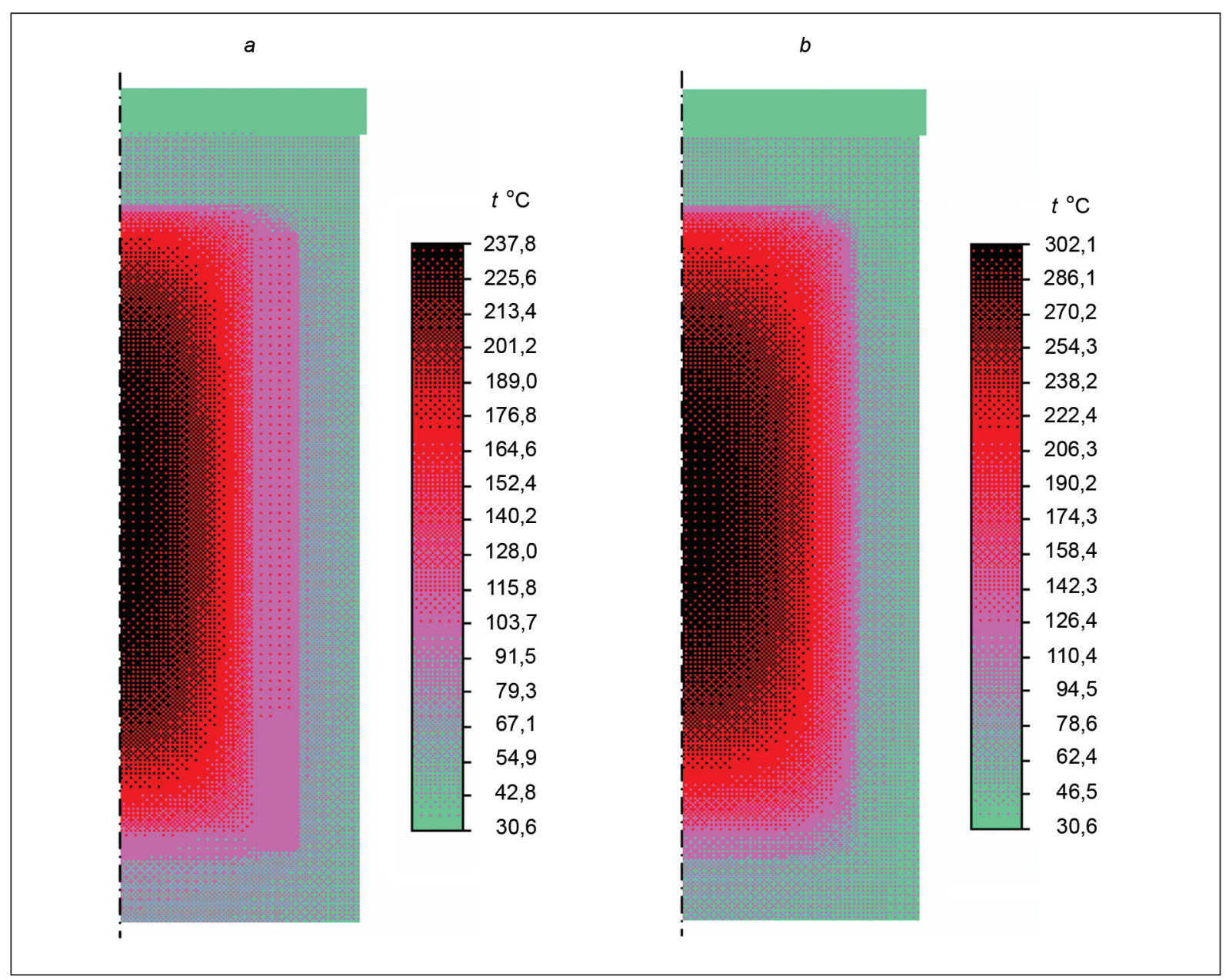

5 pav. Temperatūrų pasiskirstymas pavieniame konteineryje pirmuoju (a) ir antruoju (b) skaičiavimo atvejais 


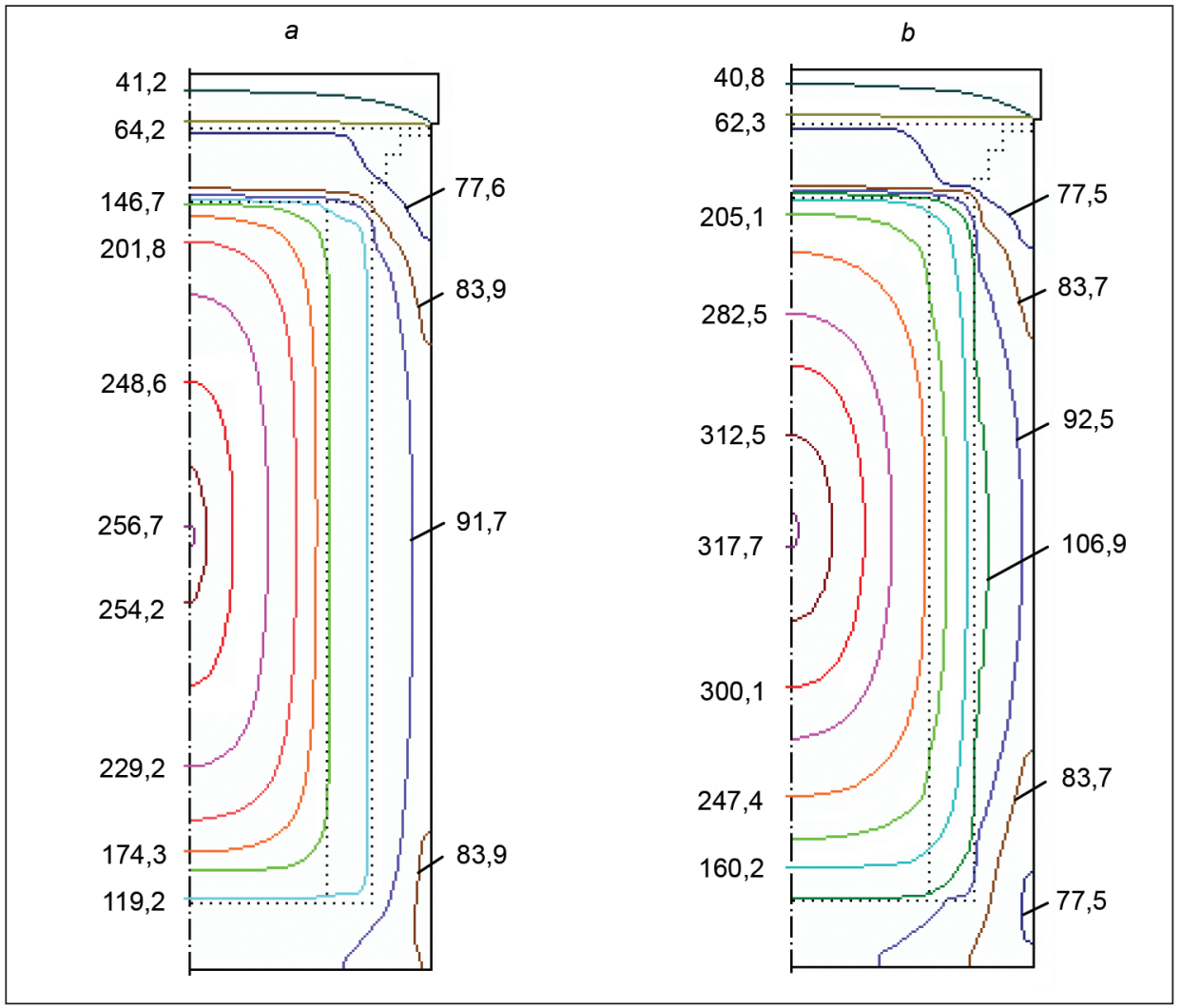

6 pav. Izotermų pasiskirstymas konteineryje, esančiame saugykloje, pirmuoju (a) ir antruoju (b) skaičiavimo atvejais

Palyginus 5 ir 6 pav. matyti, kad tiek pavieniame konteineryje, tiek konteineryje, esančiame saugykloje, pirmuoju atveju, kai žiedinio krepšio įkrovos efektinis laidumas priimamas toks kaip krepšio karkaso iš aliuminio lydinio, maksimalios ịkrovos temperatūros yra ne didesnès už maksimaliai leistiną $-300{ }^{\circ} \mathrm{C}$. Antruoju atveju, kai žiedinio krepšio įkrovos efektinis laidumas priimamas toks, kaip vidinio krepšio ịkrovos, maksimalios ịkrovos temperatūros yra šiek tiek didesnès už maksimalią leistiną temperatūrą. Tačiau realiai žiedinio krepšio su aliuminio lydinio karkasu efektinis laidumas bus tarp konservatyviai priimtų ribinių aliuminio lydinio (pirmasis atvejis) ir vidinio krepšio ịkrovos (antrasis atvejis) laidumų. Todèl maksimali leistina $300{ }^{\circ} \mathrm{C}$ temperatūra nebus viršyta.

7 pav. pavaizduotas temperatūrų kitimas pavienio konteinerio ir konteinerio, esančio saugykloje, būdingose vietose radialine ir ašine kryptimis pirmuoju skaičiavimo atveju, kai dar aiškiau išryškinti anksčiau minèti dèsningumai. Tai yra: konteinerio, esančio saugykloje, visos temperatūros yra aukštesnès negu pavienio konteinerio; nuo karščiausios vietos konteinerio centre link išorès radialine ir ašine kryptimis visos temperatūros mažěja; konteinerių dugne yra aukštesnès temperatūros negu apsauginio gaubto paviršiuje; radialine kryptimi temperatūros gradientai yra didesni negu ašine kryptimi. Akivaizdūs staigūs temperatūros kritimai ties $\sim 1 \mathrm{~m}$ spinduliu radialine kryptimi, ties $\sim 0,4, \sim 4,1$ ir $\sim 4,6 \mathrm{~m}$ ašine kryptimi yra susiję su šilumos perdavimu per helio ir oro plyšius.
Skaičiavimai taip pat atlikti konteineriams su PBK po 50 metų saugojimo saugykloje. Tai yra aktualu, nes po 50 metų tarpinio saugojimo konteineriai bus transportuojami ì galutinio saugojimo - laidojimo vietas, todèl šilumines charakteristikas reikia žinoti. Šiuo atveju 102 kuro pluoštu, patalpintų vidiniame krepšyje, liekamasis šilumos išsiskyrimas $-Q_{v}=1,85 \mathrm{~kW}$, o 80 kuro pluoštų, patalpintų žiediniame krepšyje $-Q_{z}=1,87 \mathrm{~kW}$ ir suminis liekamasis šilumos išsiskyrimas $Q=3,72 \mathrm{~kW}$. Skaičiavimai atlikti abiem anksčiau minètais atvejais.

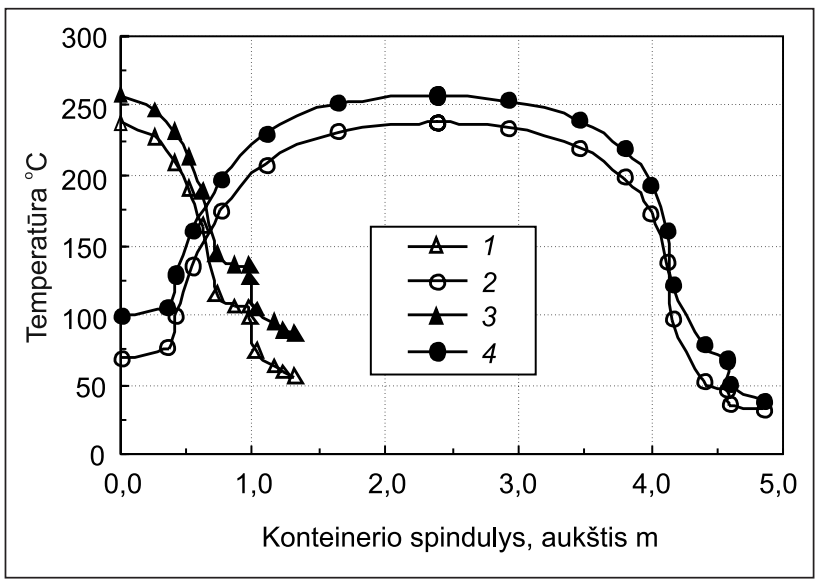

7 pav. Temperatūrų kitimas pavieniame konteineryje $(1,2)$ ir konteineryje, esančiame saugykloje, $(3,4)$ radialine $(1,3)$ ir ašine $(2,4)$ kryptimis pirmuoju skaičiavimo atveju 
Lentelè. Būdingos ribinès konteinerių temperatūros

\begin{tabular}{|c|c|c|c|c|c|c|c|c|c|}
\hline \multirow{3}{*}{$\begin{array}{l}\text { Skaičiavimo atvejis, } \\
\text { trumpa charakteristika }\end{array}$} & & \multicolumn{8}{|c|}{ Temperatūros po 5(7) ir 50 metų PBK laikymo ${ }^{\circ} \mathrm{C}$} \\
\hline & & \multicolumn{2}{|c|}{$\begin{array}{c}\text { lkrova } \\
\text { (ŠIELų paviršius) VK / ŽK }\end{array}$} & \multicolumn{2}{|c|}{$\begin{array}{l}\text { Išorinis šoninis } \\
\text { paviršius }\end{array}$} & \multicolumn{2}{|c|}{$\begin{array}{c}\text { Viršutinis gaubto } \\
\text { pavirš̌ius }\end{array}$} & \multicolumn{2}{|c|}{$\begin{array}{l}\text { Apatinis dugno } \\
\text { paviršius }\end{array}$} \\
\hline & & $7(5) \mathrm{m}$. & $50 \mathrm{~m}$. & $7(5) \mathrm{m}$. & $50 \mathrm{~m}$. & $7(5) \mathrm{m}$. & $50 \mathrm{~m}$. & $7(5) \mathrm{m}$. & $50 \mathrm{~m}$. \\
\hline \multirow{2}{*}{ 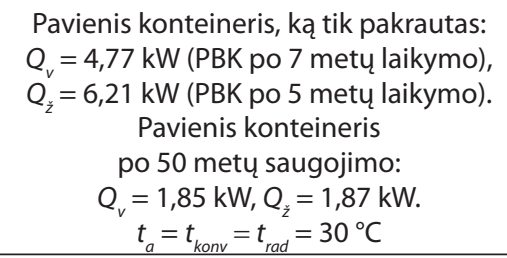 } & I & $237,8 / 107,2$ & $126,3 / 58,1$ & 56,1 & 40,2 & 32,2 & 30,9 & 69,1 & 45,2 \\
\hline & II & $302,2 / 206,8$ & $159,4 / 104,9$ & 57,9 & 40,7 & 32,3 & 31,0 & 68,3 & 45,6 \\
\hline \multirow{2}{*}{$\begin{array}{c}\text { Konteineris saugykloje, ką tik pakrautas: } \\
Q_{v}=4,77 \mathrm{~kW} \text { (PBK po } 7 \text { metų laikymo), } \\
Q_{z}=6,21 \mathrm{~kW} \text { (PBK po } 5 \text { metų laikymo). } \\
\text { Konteineris saugykloje } \\
\text { po } 50 \text { metu saugojimo: } \\
Q_{v}=1,85 \mathrm{~kW}, Q_{z}=1,87 \mathrm{~kW} . \\
t_{a}=t_{\text {konv }}=t_{\text {rad }}=35^{\circ} \mathrm{C}\end{array}$} & I & $256,7 / 135,6$ & $139,2 / 74,6$ & 87,2 & 57,4 & 39,2 & 36,9 & 98,8 & 62,1 \\
\hline & II & $317,7 / 227,4$ & $170,9 / 118,8$ & 89,8 & 58,2 & 39,1 & 36,9 & 95,4 & 61,7 \\
\hline
\end{tabular}

Visų skaičiavimų rezultatai pateikti lentelèje. Čia pateiktos būdingos ribinès temperatūros karščiausios ịkrovos vietos (ŠIEL'ų paviršiaus) vidiniame ir žiediniame krepšiuose, išorinio šoninio paviršiaus, apsauginio gaubto viršutinio paviršiaus ir dugno apatinio paviršiaus temperatūros. Kaip matyti, po 50 metų saugojimo konteinerio saugykloje maksimalios ịkrovos temperatūros siekia $140{ }^{\circ} \mathrm{C}$ (pirmuoju atveju) ir $171^{\circ} \mathrm{C}$ (antruoju atveju), šoninio paviršiaus ir dugno - 57$62{ }^{\circ} \mathrm{C}$, viršutinio gaubto $-37^{\circ} \mathrm{C}$. Lyginant konteinerius su ką tik pakrautu PBK, laikytu vandens baseinuose 7(5) metus, ir po 50 metų saugojimo saugykloje, akivaizdu, kad po 50 metų visos temperatūros yra ženkliai mažesnès: maksimalios vidinio krepšio ịkrovos temperatūros sumažèja $110-140^{\circ}$, žiedinio krepšio ịkrovos $-50-110^{\circ}$, šoninio paviršiaus $-15-30^{\circ}$, dugno $-20-30^{\circ}$ ir apsauginio gaubto - apie $2^{\circ}$. Po 50 metu konteinerių saugojimo visais atvejais maksimalios ikkrovos temperatūros yra ženkliai mažesnès už maksimalią leistiną $300^{\circ} \mathrm{C}$ temperatūrą, o išorinio paviršiaus temperatūros ne didesnès už transportuojamiems konteineriams leistiną $85^{\circ} \mathrm{C}$ temperatūrą.

Taigi, atlikus naujo tipo konteinerių $\mathrm{CONSTOR}^{\circledR}$ RBMK1500/M2 su panaudotu branduoliniu kuru, numatomu saugoti baigiamoje statyti naujojoje Ignalinos AE tarpineje saugykloje, šiluminį modeliavimą ir temperatūrų ịvertinimą, galima teigti, kad naujieji konteineriai pagal šiandieninę realią PBK laikymo vandens baseinuose situaciją tinka ilgalaikiam PBK saugojimui.

\section{IŠVADOS}

1. Panaudojus JAV sukurtą skaičiavimo kodą ALGOR, atliktas naujo tipo gelžbetoninių konteinerių CONSTOR RBMK1500/M2 panaudotam branduoliniam kurui saugoti naujojoje Ignalinos AE saugykloje šiluminis įvertinimas. Skaičiavimai atlikti: pavienio konteinerio ir konteinerio, esančio saugykloje, su ką tik pakrautu panaudotu branduoliniu kuru, prieš tai laikytu vandens baseinuose 7(5) metus, ir po 50 metų sau- gojimo saugykloje, konservatyviai prièmus ribinius žiedinio krepšio ikkrovos efektinius laidumus, sutampančius su krepšio iš aliuminio lydinio (pirmasis atvejis) arba su vidinio krepšio įkrovos (antrasis atvejis) laidumais.

2. Skaičiavimai parodè, kad pavienio konteinerio su ką tik pakrautu panaudotu branduoliniu kuru, prieš tai laikytu vandens baseinuose 7(5) metus, maksimalios įkrovos (ŠIEL’ų paviršiaus) ir konteinerio išorinio šoninio paviršiaus temperatūros pirmuoju atveju siekia 238 ir $56{ }^{\circ} \mathrm{C}$, antruoju atveju -302 ir $58{ }^{\circ} \mathrm{C}$, o konteinerio, esančio saugykloje, atitinkamos temperatūros pirmuoju atveju siekia 257 ir $87^{\circ} \mathrm{C}$, antruoju atveju - 318 ir $90{ }^{\circ} \mathrm{C}$ ir realiai yra ne didesnès už maksimalią leistiną $\left(300^{\circ} \mathrm{C}\right)$ ŠIEL'ų paviršiaus temperatūrą.

3. Po 50 metų saugojimo pavienio konteinerio ir konteinerio, esančio saugykloje, maksimalios ịkrovos temperatūros sumažèja $110-140^{\circ}$, šoninio paviršiaus - $15-30^{\circ}$ ir yra ženkliai mažesnès už maksimalią leistiną $\left(300^{\circ} \mathrm{C}\right)$ ŠIEL'ų paviršiaus temperatūrą bei ne didesnès už transportuojamiems konteineriams leistiną $85^{\circ} \mathrm{C}$ išorinio paviršiaus temperatūrą.

4. Šiluminiu požiūriu nauji konteineriai CONSTOR RBMK-1500/M2 tinka panaudoto branduolinio kuro, realiai laikyto IAE vandens baseinuose, ilgalaikiam saugojimui.

\section{Žymëjimai}

$a$ - temperatūros laidumo koeficientas $\mathrm{m}^{2} / \mathrm{s}$,

$d$ - konteinerio skersmuo $\mathrm{m}$,

$g$ - laisvojo kritimo pagreitis, $9,81 \mathrm{~m} / \mathrm{s}^{2}$,

$l$ - lemiantysis parametras $\mathrm{m}$,

$Q$ - liekamasis šilumos išsiskyrimas $\mathrm{kW}$,

$q$ - šilumos srauto tankis $\mathrm{W} / \mathrm{m}^{2}$,

$T$ - temperatūra, $T=t+273,2, \mathrm{~K}$,

$t$ - temperatūra ${ }^{\circ} \mathrm{C}$,

$\alpha$ - šilumos atidavimo koeficientas $\mathrm{W} /\left(\mathrm{m}^{2} \cdot \mathrm{K}\right)$,

$\beta$ - tūrinio plètimosi koeficientas $1 / K$,

$\varepsilon$ - juodumo laipsnis,

$\lambda$ - šilumos laidumo koeficientas $\mathrm{W} /(\mathrm{m} \cdot \mathrm{K})$, 
$v$ - kinematinio klampio koeficientas $\mathrm{m}^{2} / \mathrm{s}$,

$\mathrm{Gr}-$ Grashofo skaičius, $\mathrm{Gr}=g \beta l^{3}\left(T_{\text {kont }}-T_{a}\right) / v_{0}^{2}$,

$\mathrm{Nu}$ - Nuselto skaičius, $\mathrm{Nu}=\alpha_{\text {konv }} / / \lambda_{0}$,

$\operatorname{Pr}-\operatorname{Prandtlio~skaičius,~} \operatorname{Pr}=v_{0} / a$,

$\mathrm{Ra}-$ Reilèjaus skaičius, $\mathrm{Ra}=\mathrm{Gr} \cdot \mathrm{Pr}$.

\section{Indeksai}

0 - oras,

$a-$ aplinka,

kont - konteineris,

konv - konvekcija,

rad - radiacija,

$v$ - vidinis krepšys,

$\check{z}$ - žiedinis krepšys.

\section{Santrumpos}

7(5) - konteinerio pakrovimo schema, kai VK yra PBK, prieš tai laikytas vandens baseinuose $\geq 7$ metus, o ŽK - $\geq 5$ metus, IAE - Ignalinos atominè elektrinè,

LEI - Lietuvos energetikos institutas,

PBK - panaudotas branduolinis kuras,

ŠIEL'as - šilumą išskiriantis elementas,

TATENA - Tarptautinè atominės energijos agentūra,

VK - vidinis krepšys,

ŽK - žiedinis krepšys.

Gauta 20110510

Priimta 20110620

\section{Literatūra}

1. Kalinkin V. I., Kritskij V. G., Davidenko N. N. i dr. Tekhnologicheskii protsess perevoda OJAT RBMK-1500 s „mokrogo“ na „suchoye“ khraneniye. OAO „Golovnoi institut „VNIPIET“ i OAO „Koncern Rosenergoatom“. SanktPeterburg, Rossiya, 2010 (rusų kalba).

2. Vatulin A. V., Ioltukhovskiy A. G., Kadarmetov I. M. et al. Validation of dry storage modes for RBMK-1000 spent fuel assembles (SFA) (IAEA-CN-102/39). In: Storage of Spent Fuel from Power Reactors. Proceedings of International Conference. IAEA, Vienna, 2003. P. 422-430.

3. Technical Basis for Storage of Zircalloy-Clad Spent Fuel Inert Gases. PNL-4835. 1983.

4. Regulations for the Safe Transport of Radioactive Material. 2009 Edn. IAEA Safety Standards Series. Safety Requirements No. TS-R-1. IAEA, Vienna, 2009.

5. Rimkevicius S. et al. Comprehensive fuel data report for RBMK 1500 fuel assemblies used at Ignalina NPP. Final Report S/17-760.5.6-G-V:01. Laboratory of Nuclear Installation Safety, Lithuanian Energy Institute, 2006.

6. Poškas P., Šimonis V., Makarevičius R. Panaudoto branduolinio kuro saugojimo konteinerių šiluminis ịvertinimas. Energetika. 1999. Nr. 4. P. 20-25.

7. Poškas P., Šimonis V. Thermal analysis of casks for interim storage of RBMK-1500 spent nuclear fuel. In: Sunden B., Vilemas J. (eds.). Advances in Heat Transfer Engineering.
Proceedings of the 4th Baltic Heat Transfer Conference. Kaunas, 2003. P. 629-636

8. Lee J. C., Choi W. S., Bang K. S., Seo K. S., Yoo S. Y. Thermal-fluid flow analysis and demonstration test of a spent fuel storage system. Nuclear Engineering and Design. 2009. Vol. 239. P. 551-558.

9. ALGOR: An Interactive Demonstration. An Introduction to Steady-State Heat Transfer. Pt. No. 3118.401, Rev. 2, Pittsburgh, USA, 1992.

10. Wärmeübergang durch freie Konvektion in geschlossenen Fluidschichten. VDI-Wärmeatlas. Auflage 6, 1991. Blatt Fc. S. 66-73.

11. Kutateladze S. S. Teploperedacha i gidrodinamicheskoye soprotivleniye. Moskva: Energoatomizdat, 1990 (rusų kalba).

12. Poškas P., Beese A. ir kt. Panaudoto RBMK branduolinio kuro iš Ignalinos AE 1 ir 2 bloku laikinas saugojimas. Poveikio aplinkai vertinimo ataskaita S/14-658.5.9/EIA-R04. GNS-NUKEM (Vokietija), Lietuvos energetikos institutas, 2007.

Vytautas Šimonis, Artūras Šmaižys, Povilas Poškas

\section{THERMAL ANALYSIS OF NEW CASKS FOR SPENT NUCLEAR FUEL STORAGE AT THE NEW IGNALINA NPP STORAGE FACILITY}

Summary

The thermal analysis was performed on new-type CONSTOR RBMK-1500/M2 casks for the interim storage of spent nuclear fuel in the new storage facility at the Ignalina Nuclear Power Plant. The ALGOR numerical calculation code (USA) was used for modeling a single cask and a cask in storage, directly loading it with spent nuclear fuel pre-stored for 7(5) years in water pools and after 50 years of cask storage. The temperature distribution and the limiting cask temperatures were calculated in two cases, conservatively assuming the limiting effective thermal conductivity of a ring basket with fuel bundles, which is the same as the conductivity of a basket made of aluminum alloy (first case) or as an effective conductivity of the inner basket with fuel bundles (second case).

The maximum temperatures of fuel cladding and of the external surface in a single cask just loaded with spent nuclear fuel prestored for 7(5) years were found to reach $238{ }^{\circ} \mathrm{C}$ and $56{ }^{\circ} \mathrm{C}$ in the first case and $302{ }^{\circ} \mathrm{C}$ and $58{ }^{\circ} \mathrm{C}$ in the second case. The respective temperatures of the cask in storage reached $257^{\circ} \mathrm{C}$ and $87^{\circ} \mathrm{C}$ in the first case and $318^{\circ} \mathrm{C}$ and $90^{\circ} \mathrm{C}$ in the second case. After 50 years of cask storage in a storage facility, the maximum temperatures of fuel cladding decreased by $120-140^{\circ}$ and of the side-surface by about $30^{\circ}$. Practically, the effective thermal conductivity of the ring basket is between the conductivities of the first and second cases; therefore, for casks loaded with spent nuclear fuel pre-stored for 7(5) years, the maximum temperatures of fuel cladding will never exceed the maximum allowed temperature of $300{ }^{\circ} \mathrm{C}$. The outer surface temperatures of a single cask never exceed the allowed temperature of $85^{\circ} \mathrm{C}$ for transport casks.

Key words: RBMK-1500 spent nuclear fuel, cask, storage facility, fuel element, temperature, decay heat flux 
Витаутас Шимонис, Артурас Шмайжис, Повилас Пошкас

ТЕПЛОВАЯ ОЦЕНКА НОВЫХ КОНТЕЙНЕРОВ, ПРЕДНАЗНАЧЕННЫХ ДЛЯ ХРАНЕНИЯ

ОТРАБОТАННОГО ЯДЕРНОГО ТОПЛИВА НА НОВОМ ХРАНИЛИЩЕ ИГНАЛИНСКОЙ АЭС

Резюме

Представлена тепловая оценка новых контейнеров CONSTOR RBMK-1500/M2, предназначенных для хранения отработанного ядерного топлива на новом промежуточном хранилище Игналинской АЭС. Численное моделирование выполнено с использованием расчетного кода ALGOR (США) в одиночном контейнере и в контейнере, находящемся в хранилище, с только что загруженным отработанным ядерным топливом, предварительно выдержанным в бассейнах выдержки 7(5) лет, и после 50-летнего хранения контейнера в хранилище. Консервативно приняв предельные эффективные коэффициенты теплопроводности кольцевой корзины с пучками топлива, совпадающие с материалом корзины из алюминиевого сплава (первый случай) или с эффективной теплопроводностью внутренней корзины с пучками топлива (второй случай), определены распределение температур и предельные температуры контейнеров.

Расчеты показали, что в одиночном контейнере с только что загруженным отработанным ядерным топливом, выдержанным в бассейнах 7(5) лет, максимальные температуры оболочки ТВЭЛов и наружной боковой поверхности контейнера в первом случае достигают 238 и $56{ }^{\circ} \mathrm{C}$, а во втором - 302 и $58{ }^{\circ} \mathrm{C}$. Соответствующие температуры контейнера, находящегося в хранилище, составляют в первом случае 257 и $87^{\circ} \mathrm{C}$, а во втором - 318 и $90{ }^{\circ} \mathrm{C}$. После 50-летнего хранения контейнеров в хранилище максимальные температуры ТВЭЛов понижаются на 120-140, а боковой поверхности - примерно на $30^{\circ}$. Фактически эффективная теплопроводность кольцевой корзины находится между теплопроводностями первого и второго случаев, поэтому после 7(5)-летней выдержки топлива в бассейнах максимальные температуры ТВЭЛов не будут превышать максимально допустимую температуру $300{ }^{\circ} \mathrm{C}$, а температуры наружной поверхности одиночного контейнера не превышают допустимую температуру $85^{\circ} \mathrm{C}$ для транспортных контейнеров.

Ключевые слова: отработанное ядерное топливо RBMK1500, контейнер, хранилище, тепловыделяющий элемент, температура, остаточный тепловой поток 